\title{
ENSO and riverine control of nutrient loading, phytoplankton biomass and mussel aquaculture yield in Pelorus Sound, New Zealand
}

\author{
J. R. Zeldis ${ }^{1, *}$, C. Howard-Williams ${ }^{1}$, C. M. Carter $^{1,2}{ }^{,}$D. R. Schiel ${ }^{2}$ \\ ${ }^{1}$ National Institute of Water and Atmospheric Research (NIWA) Ltd., 10 Kyle Street, PO Box 8602, Riccarton, \\ Christchurch 8011, New Zealand \\ ${ }^{2}$ Marine Ecology Research Group, School of Biological Sciences, University of Canterbury, Private Bag 4800, \\ Christchurch 8041, New Zealand
}

\begin{abstract}
Multi-year time-series were used to describe oceanic and riverine nutrient supply and primary biomass in Pelorus Sound, a $50 \mathrm{~km}$ long estuary supporting most of New Zealand's \$200 million per annum mussel Perna canaliculus aquaculture industry. In the summer half-year (October to March), when the Southern Oscillation Index (SOI) was negative (El Niño), NNW along-shelf wind stress strengthened and sea surface temperature (SST) at the Sound entrance cooled, indicating upwelling. This triggered increases in phytoplankton biomass, particulate nitrogen (PN) and per capita yield of farmed mussels in the Sound. In the winter half-year (April to September), wind stress was unrelated to SOI, but during NNW winds Pelorus River flows increased, along with $\mathrm{NO}_{3}{ }^{-}$, phytoplankton biomass, PN and mussel yield. During an extended period of positive SOI (La Niña), SSE winds and drought during 1999 to 2002, seston (PN) abundance and its food quality decreased, concomitant with a mussel yield decrease of $~ 25 \%$ throughout Pelorus Sound. Seston and mussel yield had recovered by 2003 without reductions in farming intensity, so over-grazing by mussels did not cause the yield minimum. Instead, climatic forcing of oceanic and riverine N supply and seston biomass underlay the inter-annual variation in mussel yield. As tracers of the relationship of nutrient loading and production, $\mathrm{PN}$ and mussel yield appeared more reliable than $\mathrm{NO}_{3}{ }^{-}$or chl a concentrations. In Pelorus Sound, oceanic and riverine N supplies are seasonally complementary and sustain year-round mussel yield, although their inter-annual variability, linked to wider climate forcing, can drive considerable fluctuation in yield over the decadal scale.
\end{abstract}

KEY WORDS: Climate $\cdot$ Estuaries $\cdot$ Mussel aquaculture $\cdot$ ENSO $\cdot$ Nutrients $\cdot$ Primary biomass Resale or republication not permitted without written consent of the publisher

\section{INTRODUCTION}

Understanding the linkages between climatically driven ocean forcing and local-scale dynamics is a major challenge for marine ecologists, with ramifications not only for issues such as climate change effects, but also for locally important economic activities such as aquaculture. Climatic variability can affect ocean circulation (e.g. Blanton et al. 1987) or river flow (Malone et al. 1988) adjacent to estuaries which drive their net nutrient supply and, therefore, can be expected to have a central role in determining levels of estuarine seasonal and annual primary production. Such variability includes El NiñoSouthern Oscillation (ENSO; McPhaden et al. 2006) and other low-frequency meteorological forcing affecting oceanic or riverine nutrient supply to estuaries (e.g. Boynton et al. 1982, Peterson et al. 1985, Malone et al. 1988).

Because aquaculture of filter-feeders is so closely tied to its underlying primary production system, it can be expected that climatic variability could significantly affect aquaculture success (e.g. Blanton et al. 1987). Furthermore, in certain conditions of intensive culture, bivalve aquaculture can exert significant top-down control on its production system through grazing (e.g. 
Figueiras et al. 2002, Huang et al. 2008). These potentially confounding effects mean that it is important to have a good understanding of factors affecting estuarine productivity to enable the aquaculture industry and resource managers to separate natural climatic variability from impacts due to the farming activity itself.

As a case in point, here we consider Pelorus Sound, New Zealand (see Fig. 1). This estuary supports ca. 3/4 of the $\$ 200$ million per annum, $75000 \mathrm{t}$ green weight, national production of New Zealand greenshell mussels Perna canaliculus, which are grown on hundreds of individual farms throughout its main channel, sidearms and embayments (New Zealand Marine Farming Association 2007). The mussels are grown using suspended rope culture (Zeldis et al. 2005) and feed on phytoplankton and other suspended particles drifting through the farms. Starting in early 1999, farm productivity in the Sound declined by ca. $25 \%$ (measured in terms of per capita meat yield) followed by recovery during 2002, with substantial economic impacts and distortions within the industry (Hayden et al. 2000). Thus, a major environmental and economic incentive underscored the need to understand the drivers of historical patterns in primary biomass in Pelorus Sound to ascertain if bivalve aquaculture was forcing primary biomass variation (e.g. Huang et al. 2008) or vice-versa (e.g. Armstrong 1982). There was a need to differentiate natural forcing of primary biomass variation in the estuary from human-induced effects, i.e. potential over-grazing by large amounts of introduced secondary consumers.

Accordingly, in the present study the hypothesis was that long-term variation in the yield of Pelorus Sound mussel aquaculture arises from natural variation in estuarine system nutrient supply and productivity and is not anthropogenic. To test this, we resolved the behaviours of climatic forcing underlying terrestrial and marine nutrient loading to the Sound and their relationships with primary biomass, based on environmental time-series. Then, using industry data, we evaluated whether the forcing could explain variation in farm yield, independently of changes in farming activity. The dynamics we resolved were compared with those known for other mussel aquaculture regions internationally, because reports relating climatic variation, biogeochemical processes and mussel aquaculture performance are scarce worldwide (Kremer et al. 2000). In so doing the present study investigated relationships between nutrient loading and concentration with primary production and biomass (Boynton et al. 1982, Cloern 2001) and demonstrated that while climatic forcing of nutrient loading clearly affects Pelorus Sound primary and secondary productivity, its effects are most clearly seen in productivity-related indices which integrate over relatively long timescales of variability.

\section{MATERIALS AND METHODS}

Environmental setting. Pelorus Sound is a relatively deep (average $40 \mathrm{~m}$ ), narrow, highly indented fiordtype estuary ca. $56 \mathrm{~km}$ long at the north end of New Zealand's South Island (Fig. 1). Residence time calculations (Gibbs et al. 1992) and water, salt and nutrient mass-balance budgeting (Dupra 2000) show that exchanges with Cook Strait (Fig. 1) dominate nutrient flux to the seaward reaches of the Sound, with $95 \%$ of the nitrogen $(\mathrm{N})$ oceanic in origin. In contrast, the budget showed that the inner half of the Sound receives $60 \%$ of its $\mathrm{N}$ from its riverine input, dominated by the Pelorus River (Bradford et al. 1987).

The Pelorus River (mean inflow $\sim 20 \mathrm{~m}^{3} \mathrm{~s}^{-1}$ ) drives strong horizontal (19 to $34 \mathrm{psu}$ ) and vertical (4 to $0.2 \mathrm{psu})$ salinity gradients from the inner to outer Sound (Bradford et al. 1987). River flow rates average 18 and $22 \mathrm{~m}^{3} \mathrm{~s}^{-1}$ in summer and winter, respectively, and $\mathrm{NO}_{3}{ }^{-}$concentrations average 10 and $17 \mu \mathrm{mol} \mathrm{l}^{-1}$ (Shearer 1989), such that winter $\mathrm{NO}_{3}{ }^{-}$fluxes are twice summer fluxes. During high flows the river's influence can spread through most of the Sound (Gibbs et al. 1992). These generally occur under northerly quarter (NW-NE) winds which accompany increased rainfall in the Pelorus catchment, over the Rye and Richmond Ranges (Fig. 1; de Lisle \& Kerr 1965, Shearer 1989). River inputs also affect vertical density stratification in the Sound, potentially affecting the light environment for phytoplankton and hence productive conditions (Gibbs \& Vant 1997).

Oceanic waters adjacent to the Sound are affected by upwelled water, advected there from an intense upwelling zone at the western approaches of Cook Strait (Fig. 1; Harris 1990). The advection is driven by predominate, orographically steered NW winds through the Strait and manifested as cool water over the south side of the Strait including the Pelorus entrance area (Fig. 1) in remote sensing and ship data (Foster \& Battaerd 1985, Harris 1990). The state of ENSO could affect the strength of these upwelling dynamics, especially in summer. The mechanism is that during El Niño summers, winds tend to be more westerly (and upwelling-favourable) than during non-El Niño years, with a greater NW component as they are steered through the Strait (Gordon 1986, Mullan 1998, Harris 1990). Conversely, during La Niña summers, easterlies are more prevalent, with a greater SE component unfavourable for upwelling. Correlations between these wind directions and ENSO state become significantly weaker or non-existent outside of summer (Mullan 1998, B. Mullan, NIWA, pers. comm.).

The prior knowledge of the seasonality of river inputs and ENSO-related meteorology indicated it was appropriate to seasonally stratify our analysis of catch- 
a

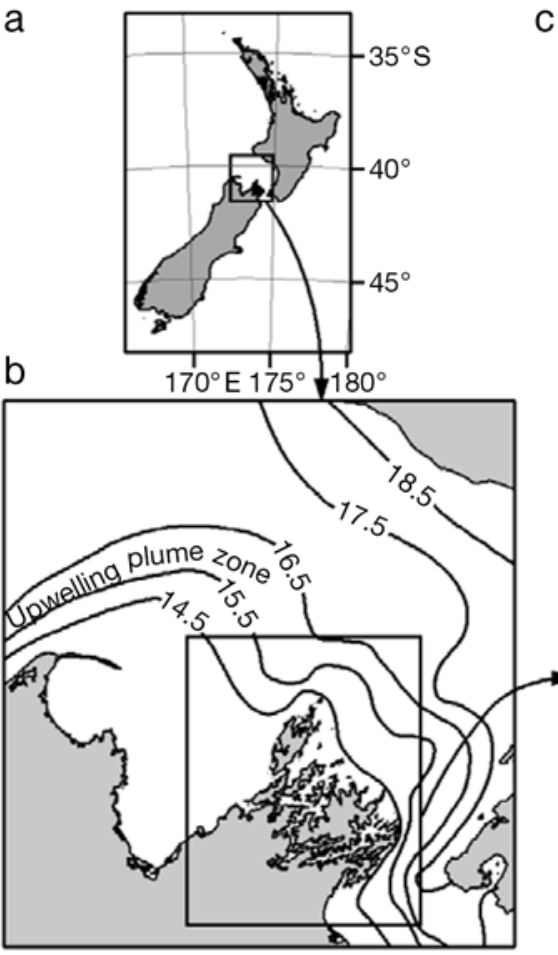

C

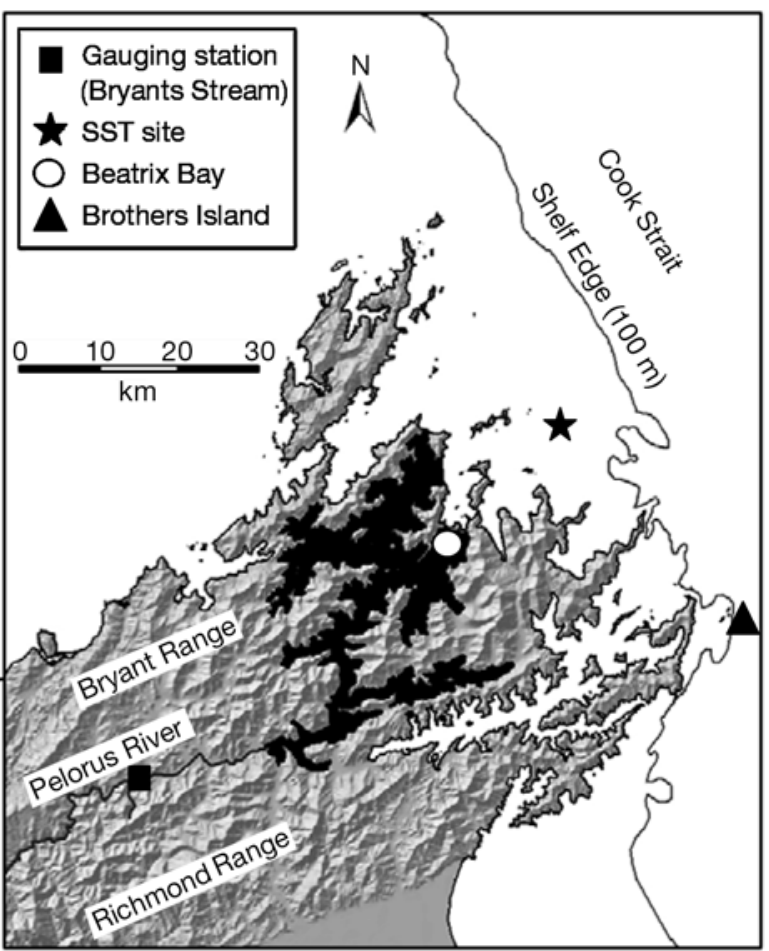

Fig. 1. (a) New Zealand, with rectangle locating the Cook Strait/Marlborough Sound region in the northern South Island. (b) Summer isotherms showing location of upwelling-affected waters in the southwestern Strait (from ship survey data collected in January to February 1980 by Bowman et al. 1982); rectangle locating the Marlborough region. (c) Pelorus Sound (black), including Beatrix Bay sampling site, the western Cook Strait continental shelf, where sea surface temperature (SST) data were recorded, Brothers Island wind gauging station and the Pelorus River flow gauging station

ment and oceanic forcing of nutrient loading and biomass formation in the Sound. We therefore stratified the data between (austral) summer (October to March) and winter (April to September) half-years and analysed these separately.

Meteorology and hydrology. The Southern Oscillation Index (SOI) measure of ENSO was obtained starting in January 1979 as the standardised anomaly of the monthly mean sea level pressure difference between Tahiti and Darwin (Australian Bureau of Meteorology www.bom.gov.au/climate). Wind velocities were obtained from Brothers Island in western Cook Strait (Fig. 1) from January 1997, using NIWA National Climate Centre databases. The continental shelf of this region has an approximate 330 to $150^{\circ}$ orientation (NNW-SSE; Fig. 1), so along-shelf wind components were calculated by adding $30^{\circ}$ to the raw bearings to align the $u$ and $v$ components of the velocity cross-shelf and along-shelf, respectively. Along-shelf wind stresses $\left(\tau_{\mathrm{as}}\right)$ were calculated (Zeldis et al. 2004) as:

$$
\tau_{\mathrm{as}}=C_{\mathrm{d}} p_{\mathrm{a}} \sqrt{\left(u_{w}^{2}+V_{\mathrm{w}}^{2}\right)} V_{\mathrm{w}}
$$

where $p_{\mathrm{a}}=1.3 \mathrm{~kg} \mathrm{~m}^{-3}$ is the air density, $u_{\mathrm{w}}$ and $v_{\mathrm{w}}$ are the components of the wind vector in the cross-shelf and along-shelf directions, respectively, and $C_{\mathrm{d}}$, the surface drag coefficient, is related to the wind speed, $w$, by:

$$
C_{\mathrm{d}}=(0.75+0.067 w) 10^{-3}
$$

Note that in the convention applied in the present study, negative values indicate wind stress blowing from the NNW, and positive values indicate stress blowing from the SSE.

Sea surface temperatures were obtained using satellite radiometer data (NIWA SST Archive; Uddstrom \& Oien 1999) from monthly means of a 3-by-3 pixel array centred on $40.90^{\circ} \mathrm{S}, 174.19^{\circ} \mathrm{E}$, at the entrance to Pelorus Sound (Fig. 1), starting in January 1993. Pelorus River flows were gauged at Bryant's Stream (Fig. 1) starting in January 1979 and calculated as in McKerchar (2002).

Nutrient and phytoplankton sampling. Nutrient and phytoplankton samples were collected weekly within Beatrix Bay, an embayment in mid-Pelorus Sound (Fig. 1), at 2 sites (West Beatrix and Laverique), using a 'tube sampler' lowered to $15 \mathrm{~m}$ depth, stoppered and retrieved, yielding an integrated water sample over that stratum. Samples were chilled, transported to the laboratory and processed within $24 \mathrm{~h}$. Sub-samples 
were filtered (GF/C glass microfiber), and the filtrate was frozen and later analysed for nitrate-plus-nitrite $\mathrm{N}$ (hereafter called $\mathrm{NO}_{3}{ }^{-}$) and total ammoniacal $\mathrm{N}\left(\mathrm{NH}_{4}{ }^{+}\right)$ on an AlpKem series 500 marine auto-analyser, postJanuary 1995. From July 1997, assays were also made for particulate nitrogen (PN) and particulate carbon (PC) using high-temperature combustion (Carlo Erba Instruments NC2500 elemental analyser) using precombusted, weighed GF/C filters. GF/C-filtered samples for chl a were assayed using acetone pigment extraction and spectrofluorometric measurement. Whole water sub-samples preserved in acid Lugol's iodine were assayed for phytoplankton taxon biomass using the inverted microscope technique (Utermöhl 1958), after conversion of cell counts to carbon (C) biomass using average cell bio-volume by species (available from October 1994). The present study reports biomass of the most important functional groups resolved by the microscopy, diatoms and dinoflagellates, which dominate Pelorus Sound primary biomass (Carter et al. 2005).

Per capita meat yield of mussels was evaluated for 8614 mussel farm long-lines harvested starting July 1997. Upon harvest, a sample of 20 mussels from each line was weighed whole, then cooked, shelled and the meat re-weighed onboard the harvesting vessel. This industry standard metric was analysed using data for harvests over all of Pelorus Sound and also for Beatrix Bay harvests only, where the chemical and biological data (described above) were collected.

Data manipulation and statistical analysis. Monthly mean wind stress, $\mathrm{SST}$, Pelorus River flow, $\mathrm{NO}_{3}{ }^{-}, \mathrm{NH}_{4}{ }^{+}$, $\mathrm{PN}, \mathrm{PC}$, diatom $\mathrm{C}$, dinoflagellate $\mathrm{C}$ and mussel yield, calculated across all years of their respective time series, were subtracted from their respective monthly means calculated within years to generate monthly anomalies, thereby removing monthly (seasonal) effects and enabling inter-annual variability to be examined. Data collected at the 2 sites within Beatrix Bay were averaged prior to this manipulation. Also analysed were the sums of $\mathrm{NO}_{3}{ }^{-}$and $\mathrm{NH}_{4}{ }^{+}$(i.e. dissolved inorganic nitrogen: DIN) and diatom and dinoflagellate C (phytoplankton C) anomalies (i.e. phytoplankton C anomalies). Non-parametric Spearman's rank-order correlation (StatSoft 2005) was used to determine strengths of relationships among variables, as examination of data revealed significant non-normality in variate distributions in a number of cases (ShapiroWilks W test). The time courses of physical and chemical variation in the Sound were examined between 1997 and 2004, during which there were complete records for all variables.

Biological variables were correlated with physical variables from the previous month, which accounted for the known turnover timescale of the Pelorus Sound water mass (ca. 20 d; Heath 1976, Dupra 2000) and for biomass changes by phytoplankton in response to changing nutrient levels (ca. 1 to 2 wk; Chang et al. 2003). Mussel yields were lagged by 2 mo with respect to physical and chemical variables and by 1 mo with respect to biological variables to account for the response of mussel yield to variable food supply and its forcing (J. Ren, NIWA, pers. comm.).

Multivariate Principal Components Analysis (PCA) was done on the correlation matrix of physical and chemical variables (StatSoft 2005), and biological variable scores were projected onto the subspace generated by the resulting physico-chemical principal components. This allowed conclusions about strength and direction of response of the biology along the major axes of physical and chemical variation.

\section{RESULTS}

\section{Temporal patterns of physical and chemical variables}

A strong El Niño (negative SOI) from winter 1997 (Fig. 2a) to winter 1998 was followed by a protracted and frequently intense La Niña (positive SOI) which lasted for 3 yr. ENSO then became weak El Niño, or neutral. During the summer of the 1997 to 1998 El Niño along-shelf wind stress anomaly (Fig. 2b) was strong from the NNW (i.e. negative). From late 1998 to early 2002, wind stress had predominate and strong SSE (i.e. positive) anomaly aligned with (but extending beyond) the La Niña period. Thereafter, wind stress was variable around neutral. SST anomaly was similar to that of along-shelf wind stress (Fig. 2b), with coolest values during negative (NNW) wind stress and warmest values during the positive (SSE) wind stress between 1998 and 2002.

Nitrate was drawn down to very low levels each summer (Fig. 2c), while regenerated $\mathrm{NH}_{4}{ }^{+}$showed broader seasonal peaks and less dynamic range. This DIN accumulated each winter when productivity was lower. Winter DIN was high in 1998, low from 1999 to 2001 and increased again during 2002 to 2004. Levels of PN and PC were high in summer and winter 1998 (Fig. 2d), declined to minimal levels in 2001 and returned to high levels during 2003. Winter DIN, PN and $\mathrm{PC}$ values broadly mirrored the multi-year pattern in wind stress and SST (Fig. 2b) with lower values during periods of SSE wind stress and warm SST. The time-series of the PC:PN ratio (Fig. 2e) was near the typical Redfield value (ca. 6.6 by moles; Redfield et al. 1963) except for a peak in 2001 to 2002 (Fig. 2e), which started during very low river flow in winter 2001 (annotated in Fig. 2e). 

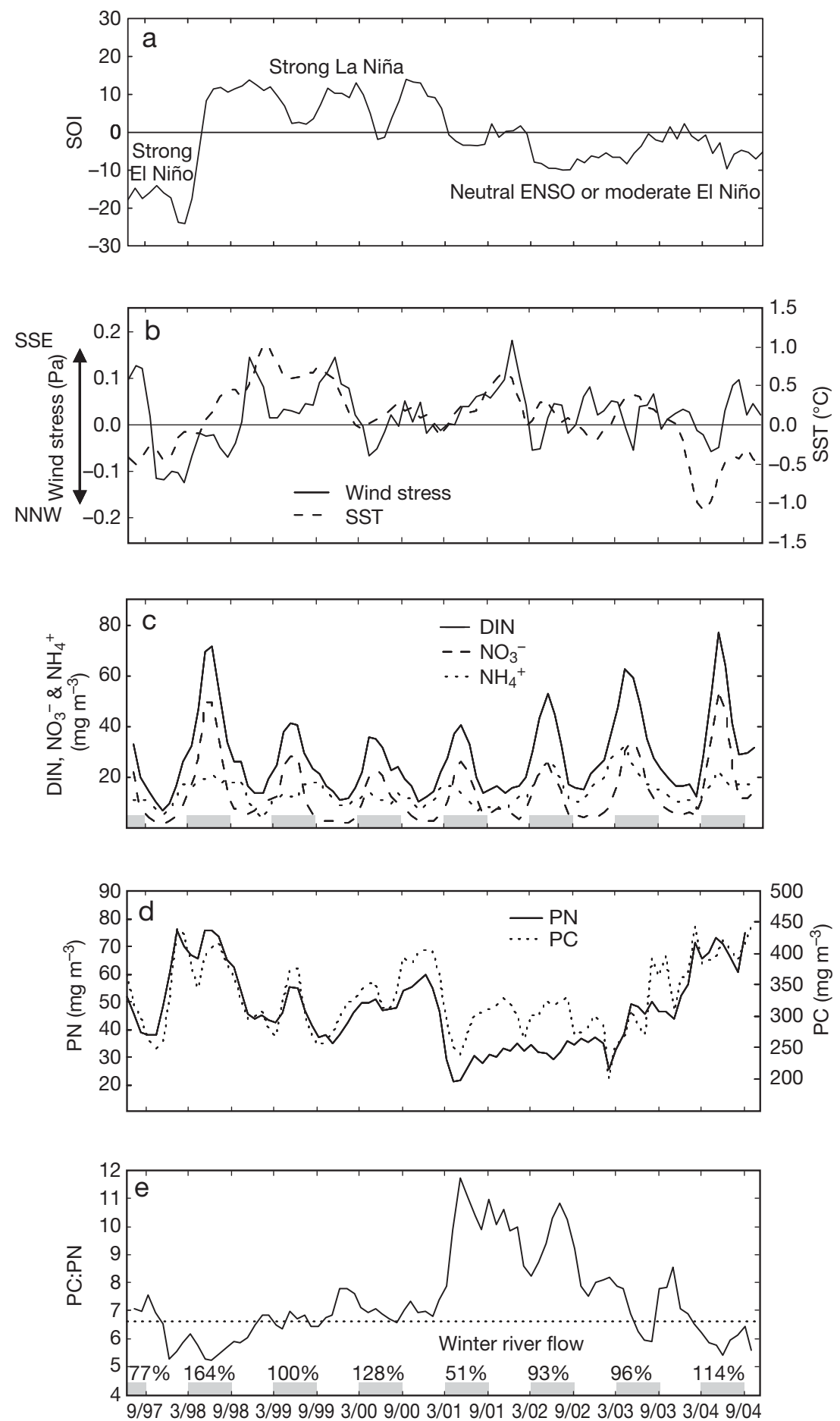

Fig. 2. Time-series of monthly mean (a) Southern Oscillation Index (SOI), (b) along-shelf wind stress anomaly (note: positive [negative] stress means wind blowing from SSE [NNW]) and Sea Surface Temperature (SST) anomaly, (c) $\mathrm{NO}_{3}{ }^{-}, \mathrm{NH}_{4}{ }^{+}$and their sum (DIN) concentrations, (d) particulate nitrogen (PN) and carbon (PC) concentration and (e) the ratio of PC and PN concentrations; dotted line, Redfield ratio. Three month running-mean smoothing was applied. Winter half-year periods were annotated with mean winter river flow (as percentage of long-term [25 yr] mean; e) to compare with PC:PN variation. For clarity, winter periods are highlighted with grey bars in panels (c) and (e)

\section{Correlations among physical, chemical and biological variables}

Anomalies of SOI, wind stress and SST were positively correlated in the summer half-year (Table 1). Thus, when SOI was negative (i.e. El Niño) in summer, NNW (negative) wind stress increased and SST at the Sound entrance cooled. Conversely, when SOI was positive (i.e. La Niña) in summer, SSE (positive) wind stress increased and SST warmed. Summer $\mathrm{NO}_{3}{ }^{-}$correlated positively with river flow but over a small dynamic range, from 0.3 to $0.6 \mu \mathrm{mol} \mathrm{l}^{-1} \mathrm{NO}_{3}{ }^{-}$ between the 5th and 95th percentiles of summer river flow (not shown). In the winter half-year, unlike in summer, neither SOI nor SST correlated with along-shelf wind stress (Table 1). Wind stress and river flow, however, were negatively correlated, with NNW wind stress associated with increased river flow. Winter $\mathrm{NO}_{3}{ }^{-}$correlated positively with river flow but with a much larger dynamic range than in summer, ranging between 1.0 and $2.3 \mu \mathrm{mol} \mathrm{l}^{-1} \mathrm{NO}_{3}{ }^{-}$between 5th and the 95th percentiles of winter river flow.

In the summer half-year wind stress and SST were negatively correlated with phytoplankton C and PN (Table 1), which increased when wind stress was negative (i.e. from the NNW), and SST cooled, indicating upwelling effects on production. Conversely, phytoplankton $\mathrm{C}$ and PN decreased when wind stress was positive (i.e. from the SSE) and SST warmed. There were also weak negative correlations $(p=0.07)$ of wind stress with diatom and chl a concentrations. There were no summer correlations of river flow or $\mathrm{NO}_{3}{ }^{-}$with any biological variables except chl a. In the winter half-year, river flow (especially) and $\mathrm{NO}_{3}{ }^{-}$were positively correlated with diatoms, phytoplankton $\mathrm{C}$, chl a and PN (Table 1). Winter was when phyto-

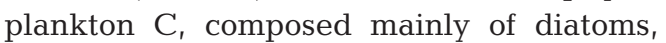
reached its annual maximum (Fig. 3) and dominated phytoplankton biomass. Marginal negative correlations ( $p=0.06$ to 0.10 ) also occurred between winter wind stress and some biological variables, reflecting the relationship of NNW anomaly with increased river flow.

In summer mussel aquaculture yield increased throughout Pelorus Sound when SOI, wind stress and SST were negative, consistent with increases following upwelling 


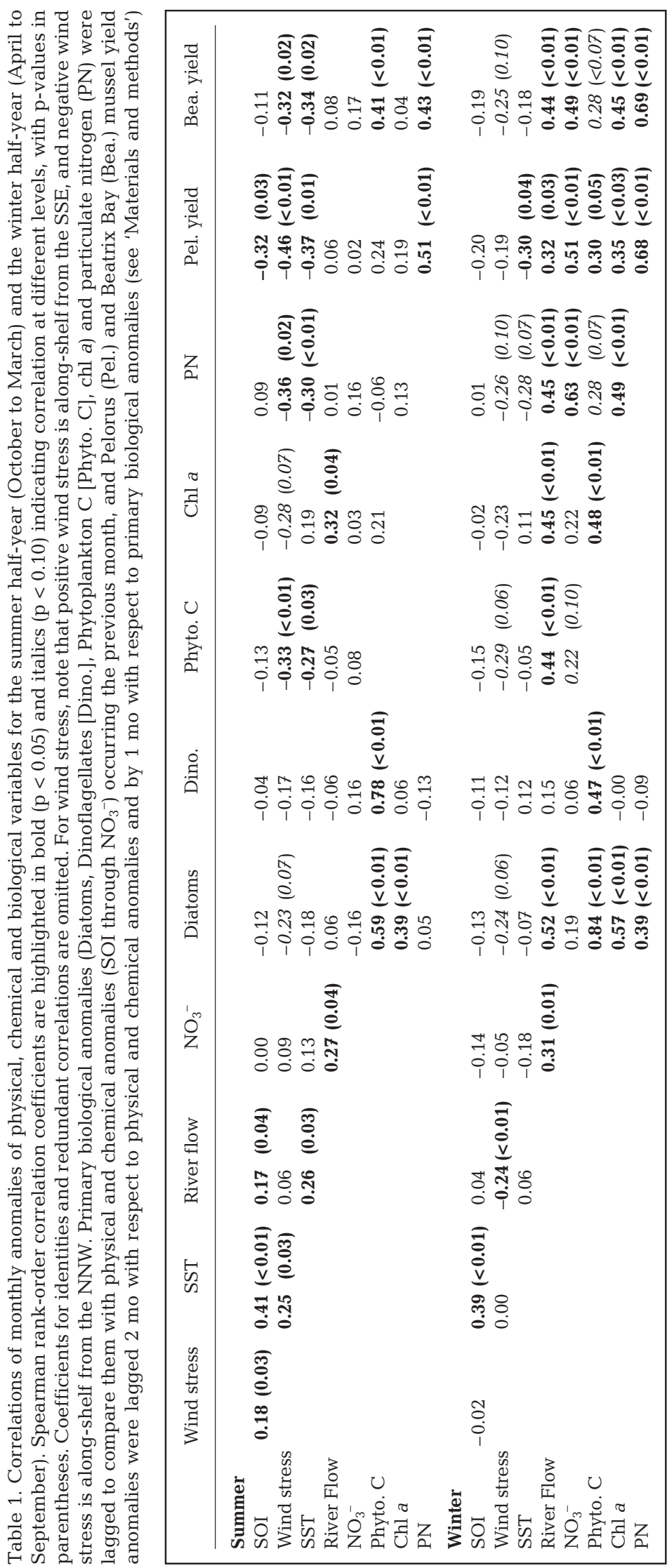

(Table 1). Yield did not correlate with river flow or $\mathrm{NO}_{3}{ }^{-}$in summer. Summer yield was, however, strongly correlated with PN throughout Pelorus and in the Beatrix Bay subset, where it also correlated with phytoplankton C. Yields were not correlated with chl $a$ in summer. In the winter half-year, yield correlated with river flow, $\mathrm{NO}_{3}{ }^{-}$, phytoplankton $\mathrm{C}$, chl $a$ and especially PN both throughout Pelorus Sound and in the Beatrix Bay subset.

Starting in 1999, mussel yield decreased by 20 to $25 \%$ (Fig. 4a) and returned to pre-1999 levels by late 2002 or early 2003. Yield fluctuated with PN through time (Fig. 4a,b). There was, however, no relationship between yield and farming activity (seeding rates; Fig. 4c). Although seeding rate fluctuated considerably from month-to-month, its long-term trend was relatively flat, both throughout Pelorus Sound and for the Beatrix Bay data subset.

The individual correlations (Table 1) were summarised using PCA (Fig. 5). In summer, principal components 1 and 2 together accounted for $62 \%$ of total variance (Fig. $5 a$ ) in the physical variables. When the biological variables were projected onto these principal components, a number of them (diatoms, phytoplankton C, PN and mussel yield) formed a coherent, negative mapping with respect to ENSO/upwelling-related physical variables (SOI, wind stress and SST). This was consistent with upwelling having a coherent, positive effect on these biological variables in summer. River flow and $\mathrm{NO}_{3}{ }^{-}$were orthogonal to, and therefore uncorrelated with, the ENSO/ upwelling-biology mode. Chl $a$ and dinoflagellates were only weakly correlated with that mode.

In winter, the first 2 principal components accounted for $64 \%$ of total physical variable variance (Fig. 5b). The anti-correlation of wind stress with river flow and $\mathrm{NO}_{3}{ }^{-}$, and the positive correlation of river flow, $\mathrm{NO}_{3}{ }^{-}$and all biological variables except dinoflagellates, was consistent with the positive influence of winter NNW wind stress on river flow and $\mathrm{NO}_{3}{ }^{-}$ loading, and the positive effects of river flow on most biological variables including mussel yield. SOI and SST mapped orthogonally to the river-flow-biology mode and were therefore uncorrelated with it.

\section{DISCUSSION}

\section{Mechanisms of nutrient supply supporting primary biomass formation}

The present study has described intra- and interannual variation in oceanic and riverine forcing of nutrient supply to Pelorus Sound and the consequent formation of biomass (summarised in Fig. 6). During 


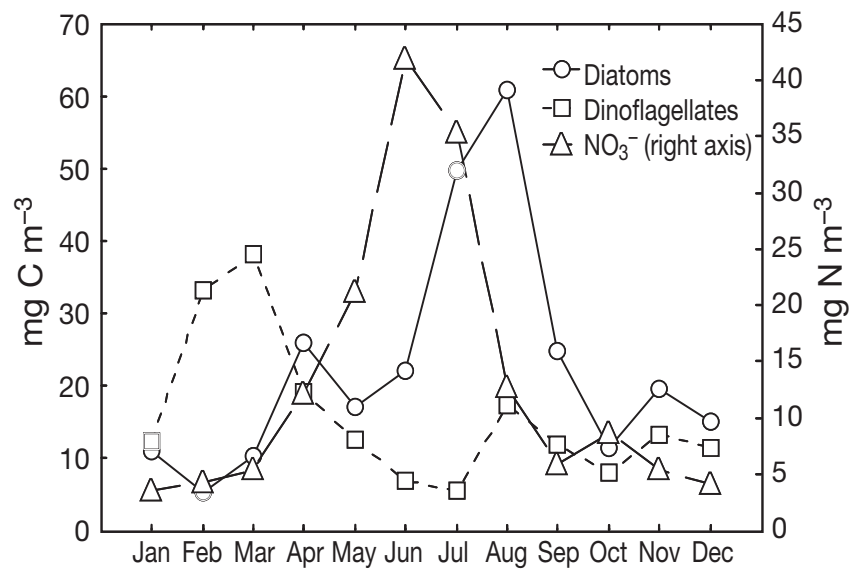

Fig. 3. Monthly mean cell carbon for diatoms, dinoflagellates and $\mathrm{NO}_{3}{ }^{-}$from weekly samples averaged over 1994 to 2005, in Beatrix Bay, central Pelorus Sound
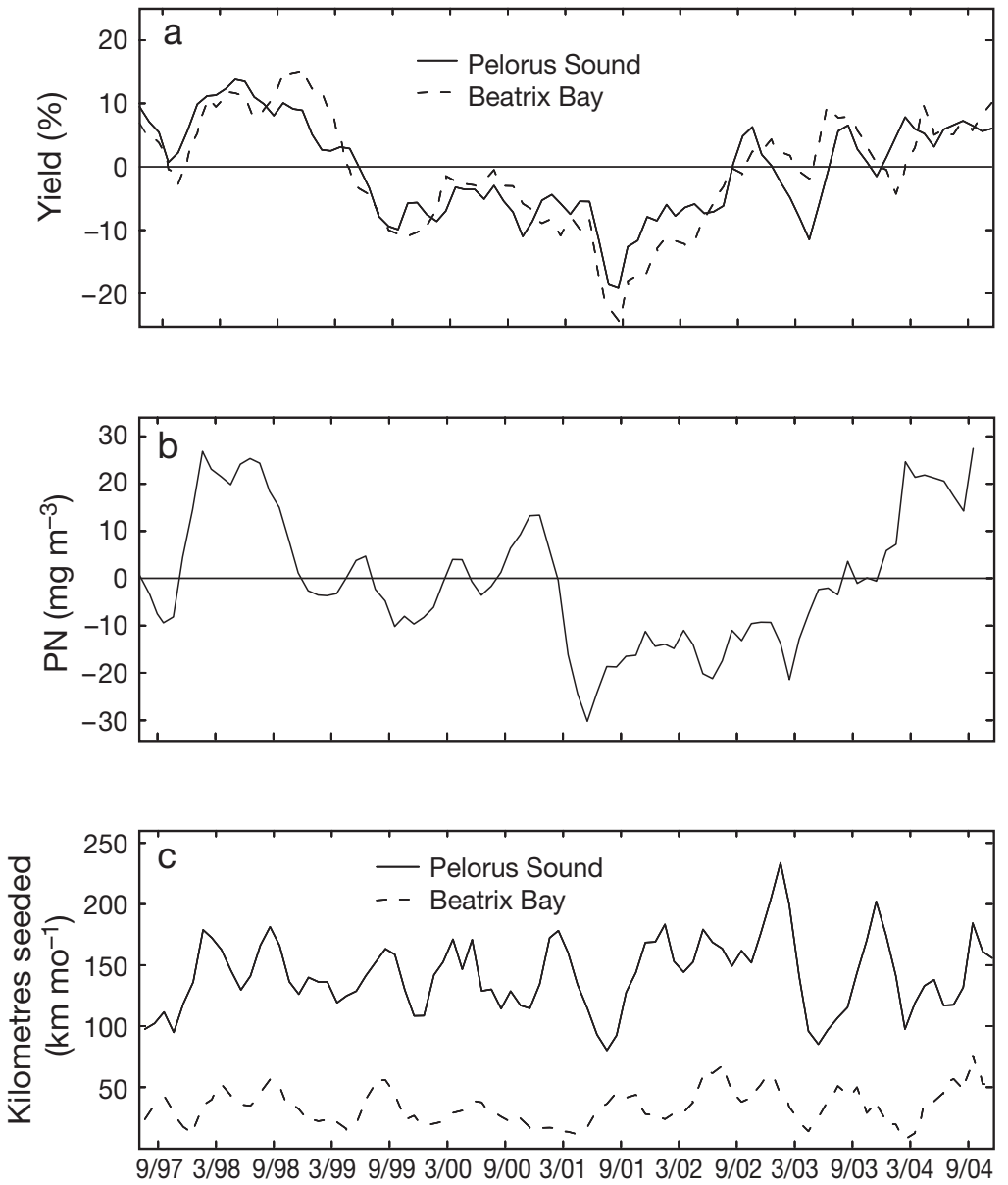

Fig. 4. Time-series of (a) monthly mean anomalies of yield of mussels harvested from farms throughout Pelorus Sound and in Beatrix Bay only (as \%), (b) monthly mean anomalies of particulate nitrogen (PN) and (c) monthly summed kilometres of mussel droppers seeded throughout Pelorus Sound and in Beatrix Bay only. (a) and (c) are plotted with respect to harvest date. Three-month running-mean smoothing was applied the summer half-year, when SOI was negative (El Niño), NNW (negative) wind stress increased and SST cooled, and when SOI was positive (La Niña), SSE (positive) wind stress increased and SST warmed (Fig. 6a). This wind response to SOI in summer was consistent with previous New Zealand studies (Gordon 1986, Mullan 1998) and indicated increased upwelling- and downwelling-favourable conditions, under NNW and SSE wind conditions, respectively, in western Cook Strait waters (Harris 1990). In El Niño, the orographic steering of westerly winds into the NW quarter through Cook Strait creates dynamical conditions favouring advection of upwelled waters through the southwestern Strait toward the Pelorus Sound entrance (Harris 1990). During these conditions, phytoplankton $\mathrm{C}$ and PN increased in the Sound (Fig. 6a), although no effects were observed on $\mathrm{NO}_{3}{ }^{-}$(discussed further below). Summer river flow, although correlated with $\mathrm{NO}_{3}{ }^{-}$, did not correlate with any primary biomass variables except chl $a$, reflecting the low $\mathrm{NO}_{3}{ }^{-}$loading rates of the Pelorus River in summer (Shearer 1989, Environmental Setting). These behaviours were reflected by the summer PCA, i.e. the orthogonal relationships of river flow and $\mathrm{NO}_{3}^{-}$with the ENSO/upwelling-biology mode.

The winter half-year showed different relationships (Fig. 6b). Wind stress correlated with river flow, but not with SOI. River flow increased during NNW winds, consistent with the known patterns of winter rainfall in the Pelorus catchment (de Lisle \& Kerr 1965). Increased river flows correlated with increased productivity indices $\left(\mathrm{NO}_{3}{ }^{-}\right.$, diatoms, phytoplankton $\mathrm{C}$, chl $\mathrm{a}$ and $\mathrm{PN}_{\text {; }}$ Fig. 6b), as in other strongly river-affected estuaries (Boynton et al. 1982, Boynton \& Kemp 2000). Upwelling in western Cook Strait is unlikely to introduce new $\mathrm{N}$ to the Pelorus entrance in winter because Cook Strait is fully vertically mixed then (Harris 1990). The winter PCA reflected these behaviours, showing no relationships of biology with SOI and SST, but positive relationships of biomass with river flow and $\mathrm{NO}_{3}{ }^{-}$, which in turn were correlated with NNW (i.e. negative) wind stress. Overall, the results show that large-scale meteorological forcing plays a significant role in biomass variability in Pelorus Sound in summer and winter. The meteorology responds to ENSO, but only in summer. The large-scale forcing driving winter meteorological patterns was not resolved, but it nevertheless appears important for driving biomass variation. 

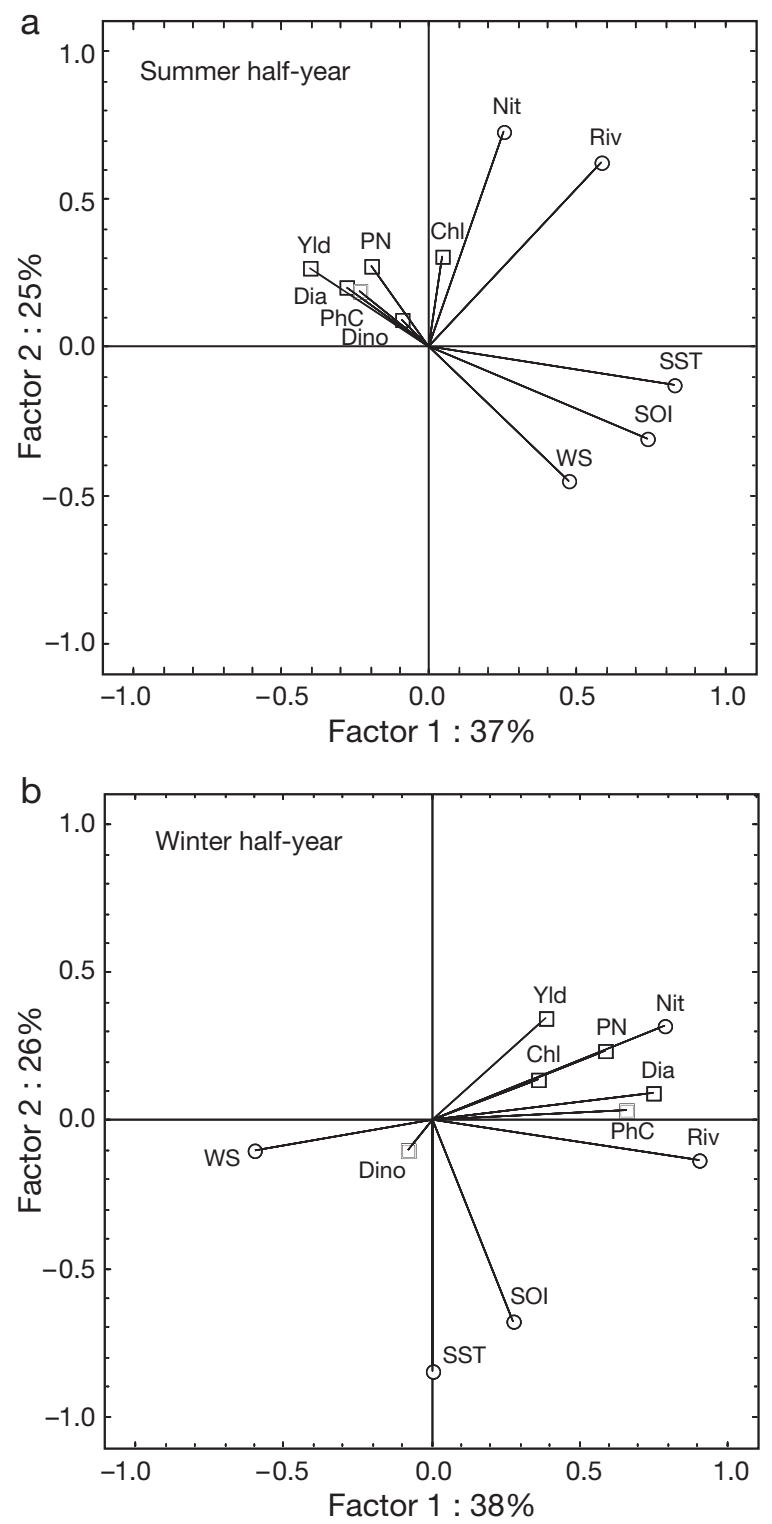

Fig. 5. Principal components analysis (PCA) on the correlation matrix of (O) physical variables with (口) biological variables projected onto the subspace generated by physical principal components 1 and 2 for (a) summer and (b) winter half-years. SOI: Southern Oscillation Index; SST: sea surface temperature; WS: along-shelf wind stress; $\mathrm{Nit}: \mathrm{NO}_{3}{ }^{-}$; Riv: Pelorus River flow; Dia: diatoms; Dino: dinoflagellates; PhC: phytoplankton (diatoms plus dinoflagellates) $C_{i}$ PN: particulate $N_{i}$ Yld: Pelorus Sound mussel yield. The percentages of total variance explained by principal components 1 and 2 are shown on the axes

\section{Relating nutrient loading, nutrient levels and biomass}

Relationships between nutrient loading, nutrient levels and primary biomass in estuaries are often not simple (Cloern 2001). Boynton et al. (1982) and Monbet (1992) showed that among estuaries with widely varying DIN concentration, there were positive relation-

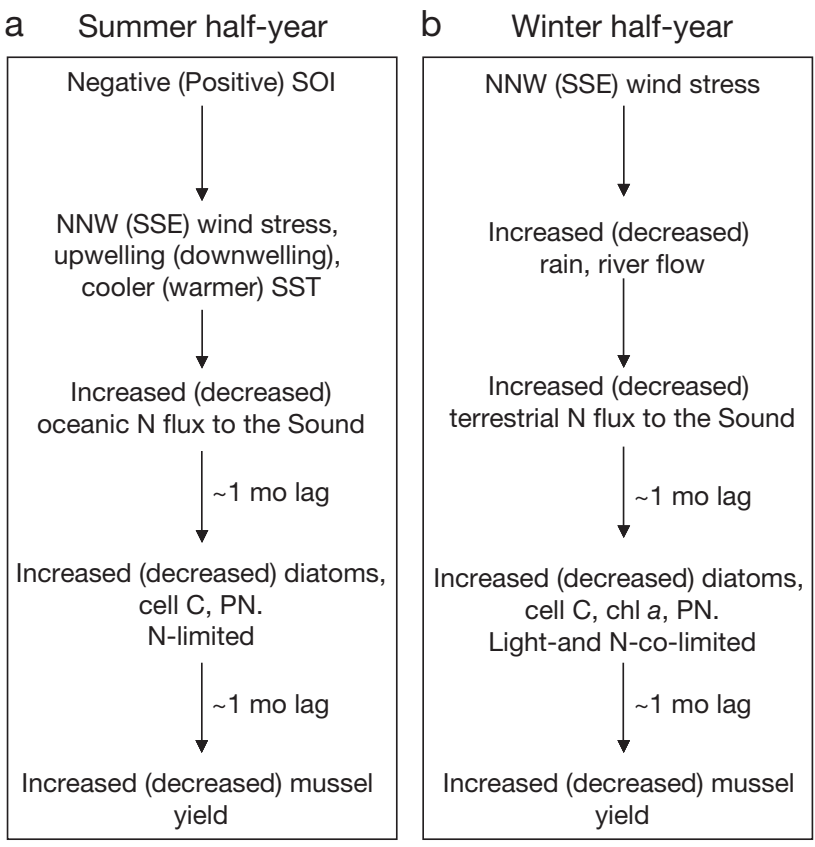

Fig. 6. Schematic of processes governing primary biomass formation and mussel yield in Pelorus Sound, as indicated by the correlations (Table 1) and principal components analyses (Fig. 5) in (a) summer and (b) winter half-years. See 'Discussion' for further explanation

ships between nutrient levels and chl a. However, there was much variability in these relationships, which was explained only with stratification of the datasets and consideration of covariates. In Pelorus Sound, upwelling and biological variables were uncorrelated with $\mathrm{NO}_{3}{ }^{-}$in summer. Primary biomass in the Sound is nutrient-limited from spring to autumn (Gibbs \& Vant 1997, Carter et al. 2005) and new $\mathrm{NO}_{3}{ }^{-}$is rapidly depleted by high primary productivity (Mackenzie \& Gillespie 1986, Vincent et al. 1989, Gibbs \& Vant 1997), consistent with the close coupling of summer productivity and $\mathrm{NO}_{3}{ }^{-}$stock depletion often seen in other temperate estuaries (Boynton et al. 1982). The fixed material is turned over quickly and the recycled DIN does not accumulate (Gibbs et al. 1992). This decouples $\mathrm{NO}_{3}{ }^{-}$concentration from its flux, eliminating its correlation with upwelling and its biological products. This effect in nutrient-limited conditions represents one mechanism by which nutrient:biomass proportionalities may be obscured in estuaries (Boynton et al. 1982).

In winter, productivity in the Sound is usually limited by light (Gibbs \& Vant 1997). However, these authors also showed (their Figs. 4 \& 5) that winter primary biomass frequently underwent large increases within surface blooms. These reached maximal biomasses that were proportional to the $\mathrm{NO}_{3}{ }^{-}$concentration present a few weeks earlier, drawing upper column $\mathrm{NO}_{3}{ }^{-}$con- 
centrations down to low levels. These winter biomass peaks occurred when the pycnocline became shallower during freshwater inflow events, which can improve light conditions for phytoplankton growth by maintaining cells within shallow euphotic depths (Mann \& Lazier 1991, Cloern 1999). This compound effect of light and nutrient supply could explain the increased winter primary biomass in the Sound during increased flows and also the stronger relationships between river flow and primary biomass, than between $\mathrm{NO}_{3}{ }^{-}$and primary biomass (Table 1 ). Thus, the relationship of $\mathrm{NO}_{3}^{-}$concentration and biomass in Pelorus Sound is not direct, being affected by strong nutrient limitation in summer and co-limiting effects of light and nutrients in winter (Fig. 6). This indicates complexity in relationships of nutrient loading, nutrient stock size and primary biomass in estuaries.

\section{Seston composition, dynamics and ecological role}

The particulate organic material (indexed by $\mathrm{PN}$ ) comprising the seston pool in the water column was composed of more than just living phytoplankton cells. By converting phytoplankton $\mathrm{C}$ to phytoplankton $\mathrm{N}$ using the Redfield ratio and dividing into PN, phytoplankton $\mathrm{N}$ was found to contribute only $16 \%$ of PN on average. Most suspended biomass was not in living cells, similar to Skidaway River Estuary, USA, where most suspended material was detrital (Verity 2002). Although picophytoplankton were uncounted here, they contribute only an average of $29 \%$ to phytoplankton C in central Pelorus Sound (Safi \& Gibbs 2003). Furthermore, mesozooplankton enumerated in Beatrix Bay in October 1997 to October 1999 contributed only an average of $2 \mathrm{mg} \mathrm{N} \mathrm{m}^{-3}$ to suspended PN (J. R. Zeldis unpubl. data), far less than the total PN values in the bay ( 30 to $80 \mathrm{mg} \mathrm{N} \mathrm{m}^{-3}$; Fig. $2 \mathrm{~d}$ ). Thus, PN was dominated by detritus, and its abundance signified it as a major pool of fixed $\mathrm{N}$ important in biogeochemical cycling and trophic functioning of the Sound (e.g. Smith et al. 1991, Bianchi 2007). This shows it is important to understand the dynamics of the whole PN fraction, inclusive of phytoplankton and detritus, when considering the relationships of physical and chemical forcing to primary biomass formation in estuaries.

Over 7 yr in Pelorus Sound there was a ca. 2-fold, low-frequency variation in $\mathrm{PN}$ from a maximum in 1998 to a minimum from 2001 to 2003, followed by recovery. This was likely to have been driven by variable flux of new $\mathrm{NO}_{3}{ }^{-}$to the system (e.g. Eppley et al. 1977, Verity 2002). The PN (seston) pool is the nutritional basis for mussel aquaculture in Pelorus Sound and elsewhere in the world (e.g. Smaal \& van Stralen 1990, Figueiras et al. 2002, Strohmeier et al. 2005), and farm per capita yield responded to its variation during 1999 to 2003. In addition, the quality of this food was also reduced during much of the food minimum, when PC:PN was substantially elevated over the particulate Redfield value indicating N-stress in the system. The largest increase in PC:PN occurred during a drought in 2001 when river flow was very low. The low flow indicated that the high $\mathrm{C}: \mathrm{N}$ was not caused by introduction of large amounts of terrestrial plant material (which has high C:N; Bianchi 2007). It was more likely that the material was largely of marine origin which was scavenged of $\mathrm{N}$ by selective loss of proteinaceous material (Bianchi 2007) during a period of very low dissolved $\mathrm{N}$ flux from the catchment and the ocean.

\section{Biological indices of chemical and physical forcing}

Some of the strongest and most consistent correlations in both summer and winter were between mussel yield and PN and between these variables and physical nutrient loading indices. In contrast, chl a was unrelated or only weakly related to physical indices, $\mathrm{PN}$ and mussel yield in summer. PN, being largely detrital, is formed by both autotrophic and more slowly varying heterotrophic processes and so may more reliably reflect low-frequency variation in nutrient loading to the system than purely autotrophic indices such as chl a (Boynton et al. 1982). Also, because only a relatively small part of PN was living phytoplankton, it could have had quite variable chl a content without its overall stock size changing greatly (e.g. Malone et al. 1988). This could add noise to relationships of chl a with nutrient loading or mussel yield, while not greatly affecting such relationships with PN. Finally, in summer the phytoplankton assemblage was approximately evenly apportioned between diatoms and dinoflagellates, whereas in winter it was predominately diatoms. Because dinoflagellates have substantially different chl a:PC and chl a:PN than diatoms (Chan 1980, Cullen 1982), the mixture of these types in summer may have added noise to chl a correlations with the other indices.

Mussel yield, as well as being strongly related to PN, was also well correlated with NNW wind stress and river flow in summer and winter, respectively. Thus, it appeared to be a reliable indicator of system nutrient loading and productivity. There are few studies linking filter-feeder success to biogeochemical forcing in the marine environment (Kremer et al. 2000). In the case of Armstrong (1982), who found positive linkages of shellfish harvest and nutrient loading in 6 Texas estuaries, a cross-system comparison was used. In our case, effects were sufficiently large and well resolved within long time-series to capture them within one system (Pelorus Sound). This indicated the integrative nature 
of mussel yield in response to variability in underlying food supply, in terms of mussel growth, energy storage and loss, and that yield of bivalve suspension-feeders can reveal relations of nutrient loading to production in estuaries. Overall, the results showed that indices such as detrital concentrations or production of secondary consumers are useful for explaining relationships of nutrient loading to production in estuaries (Cloern 2001).

\section{Drivers of mussel yield}

The mussel yield depression had substantial economic impact on the New Zealand mussel industry and led to concerns at the time that the industry had reached a size that was depleting planktonic food beyond a 'sustainability limit' (Hayden et al. 2000). The present study provides solid evidence that this was not the case, given that mussel yield recovered strongly after the yield minimum without reductions in farm stocking rates by the industry. During the recovery, food quantity and quality increased, and physical conditions returned to those expected to favour $\mathrm{N}$ flux to the Sound. We therefore accept the present study hypothesis that the mussel yield fluctuations were driven by low-frequency environmental variation and not over-development of aquaculture and over-grazing of mussel food supply.

Relationships of Perna canaliculus mussel growth to food supply have been described in physiological modelling (Ren \& Ross 2005), but ours is the first fieldbased demonstration of food-driven effects on mussel farm yield in New Zealand. Internationally, correlations of mussel growth and condition with food supply have been demonstrated in several cases (reviewed in Figueiras et al. 2002). However, there appears to be only one other report relating performance of bivalve aquaculture to inter-annual climatic forcing of variable food supply. Blanton et al. (1987) showed strong responses of mussel production to seasonal upwelling/ downwelling dynamics and associated variation in phytoplankton biomass and production in the Galician Ría system of northwestern Spain, which supports the most intensive mussel culture in Europe. Long timeseries of industry-based marine environmental and mussel yield data, in combination with national remote sensing, meteorological and hydrometric databases, have now revealed these relationships in New Zealand.

Unlike the large inter-annual variation, intra-annual yield variation is relatively small in Pelorus Sound mussels, apart from some loss in condition in midwinter during spawning $(\sim 10 \%)$. This may indicate that summer upwelling- and winter riverine-driven primary biomass provide a complementary, 'buffering' effect on variation in mussel production throughout the year, such that growth and condition remain relatively steady year-round. This contrasts with the Galician Rías, where the strong $\mathrm{N}$ inputs in summer from upwelling but little $\mathrm{N}$ input in winter (Blanton et al. 1987, Figueiras et al. 2002) results in growth rates and conditions 2- to 3-fold higher in summer than winter (Babarro et al. 2000). These contrasting modes of estuarine nutrition and seasonality of production between the Rías and Pelorus Sound represent fundamental differences between these globally important musselproducing regions that are important for understanding variation in their aquaculture yield.

\section{CONCLUSIONS}

The present study has examined oceanic and riverine forcing of intra- and inter-annual variation in the supply of $\mathrm{N}$ to primary producers, the formation of sestonic biomass and the relationships of these dynamics to farmed mussel yields in Pelorus Sound (Fig. 6). Our results have corroborated findings from earlier studies showing that both oceanic and riverine nutrient inputs significantly affect Pelorus Sound nutrient flux (Gibbs et al. 1992, Dupra 2000), but have also revealed a seasonal shift in their relative influence. This provides a seasonally complementary, stabilising influence on primary biomass formation and mussel yield, but can also exert significant inter-annual variation in these measures. This is consistent with the Galicia region where good growth and condition rely on good seston quantity and quality, but differs in regard to the seasonal balance of oceanic and riverine influences on productivity.

While linkages between large-scale environmental drivers (i.e. SOI, wind stress and river flow) and aquaculture yield in Pelorus Sound are evident, intermediate linkages need more study (e.g. the effects of summer upwelling in Cook Strait on $\mathrm{N}$ flux to the Sound and the meteorological drivers of riverine $\mathrm{N}$ flux and stratification in winter). Also in need of study is the relative influence of the oceanic and riverine endmembers, in respect of their effects on mussel production along the ocean-river axis of the Sound. Hypotheses generated by the present study can be used to guide this research.

Acknowledgements. We thank Dr. A. Ross for his insights into the work that underlies this paper over several years. We are grateful to the Marlborough Sounds Shellfish Quality Programme and Sealord Shellfisheries Ltd., which collected the marine and mussel-yield time-series, respectively. We acknowledge the NIWA Remote Sensing, Climate and Hydrometric Centres for data. The Cawthron Institute (NZ) ana- 
lysed the phytoplankton samples. We thank 2 anonymous reviewers for comments and the New Zealand Foundation for Research, Science and Technology 'Sustainable Aquaculture' programme (C01X0507) for project support and the University of Canterbury for a Top Achiever Doctoral Scholarship to C.M.C.

\section{LITERATURE CITED}

Armstrong NE (1982) Response of Texas estuaries to freshwater inflows. In: Kennedy VS (ed) Estuarine comparisons. Academic Press, New York, p 103-120

Babarro JMF, Fernández-Reiriz MJ, Labarta U (2000) Growth of seed mussel (Mytilus galloprovincialis LMK): effects of environmental parameters and seed origin. J Shellfish Res 19:187-193

Bianchi TS (2007) Biogeochemistry of estuaries. Oxford University Press, Oxford

Blanton JO, Tenore KR, Castillejo F, Atkinson LP, Schwing FB, Lavin A (1987) The relationship of upwelling to mussel production on the rias of the western coast of Spain. J Mar Res 45:497-511

Bowman MJ, Foster BA, Lapennas PP (1982) Ocean water properties. In: Kibblewhite AC, Bergquist PR, Foster BA, Gregory MR, Miller MC (eds) Maui development environmental study report on phase two 1977-1981. University of Auckland for Shell BP and Todd Oil Services, Auckland, p 77-97

Boynton WR, Kemp WM (2000) Influence of river flow and nutrient loads on selected ecosystem processes - a synthesis of Chesapeake Bay data. In: Hobbie JE (ed) Estuarine science: a synthetic approach to research and practice. Island Press, Washington, DC, p 269-298

Boynton WR, Kemp WM, Keefe CW (1982) A comparative analysis of nutrients and other factors influencing estuarine phytoplankton production. In: Kennedy VS (ed) Estuarine comparisons. Academic Press, New York, p 103-120

Bradford JM, Chang FH, Baldwin R, Chapman B, Downes M, Woods, P (1987) Hydrology, plankton, and nutrients in Pelorus Sound, New Zealand, July 1981 and May 1982. NZ J Mar Freshw Res 21:223-233

Carter CM, Ross AH, Schiel DR, Howard-Williams C, Hayden B (2005) In situ microcosm experiments on the influence of nitrate and light on phytoplankton community composition. J Exp Mar Biol Ecol 326:1-13

Chan AT (1980) Comparative physiological study of marine diatoms and dinoflagellates in relation to irradiance and cell size. II. Relationship between photosynthesis, growth and carbon/chlorophyll a ratio. J Phycol 16:428-432

Chang FH, Zeldis J, Gall M, Hall J (2003) Seasonal and spatial variation of phytoplankton assemblages, biomass and cell size from spring to summer across the northeastern New Zealand continental shelf. J Plankton Res 25:737-758

Cloern JE (1999) The relative importance of light and nutrient limitation of phytoplankton growth: a simple index of coastal ecosystem sensitivity to nutrient enrichment. Aquat Ecol 33:3-15

Cloern JE (2001) Our evolving conceptual model of the coastal eutrophication problem. Mar Ecol Prog Ser 210: $223-253$

Cullen JJ (1982) The deep chlorophyll maximum: comparing vertical profiles of chlorophyll a. Can J Fish Aquat Sci 39: 791-803

de Lisle JF, Kerr IS (1965) The climate and weather of the Nelson region New Zealand. NZ Meteorol Serv Misc Pub 115(3)
Dupra V (2000) Pelorus Sound New Zealand N and P budgets. LOICZ Biogeochemical Modelling Node, http://nest. su.se/mnode/New_Zealand/PelorusSound/Pelorusbud.htm

Eppley RW, Harrison WG, Chisholm SW, Stewart E (1977) Particulate organic material in surface waters off Southern California and its relationship to phytoplankton. J Mar Res 35:671-696

Figueiras FG, Labarta U, Fernández Reiriz MJ (2002) Coastal upwelling, primary poduction and mussel growth in the Rías Baixas of Galicia. Hydrobiologia 484:121-131

Foster BA, Battaerd WR (1985) Distribution of zooplankton in a coastal upwelling in New Zealand. NZ J Mar Freshw Res 19:213-226

Gibbs MM, Vant WN (1997) Seasonal changes in factors controlling phytoplankton growth in Beatrix Bay, New Zealand. NZ J Mar Freshw Res 31:237-248

Gibbs MM, Pickmere SE, Woods PH, Payne GW, James MR (1992) Nutrient and chlorophyll a variability at six stations associated with mussel farming in Pelorus Sound, 1984-85. NZ J Mar Freshw Res 26:197-211

Gordon ND (1986) The southern oscillation and New Zealand weather. Mon Weather Rev 114:371-387

Harris TFW (1990) Greater Cook Strait: form and flow. New Zealand Oceanographic Institute, DSIR Marine and Freshwater, Wellington

Hayden B, Ross A, James M, Hadfield M, Gibbs M (2000) Carrying capacity: the way to sustainable shellfish production. Aquaculture Update 25:7-9

Heath RA (1976) Broad classification of New Zealand inlets with emphasis on residence times. NZ J Mar Freshw Res 10:429-444

> Huang CH, Lin HJ, Huang TC, Su HM, Hung JJ (2008) Responses of phytoplankton and periphyton to systemscale removal of oyster-culture racks from a eutrophic tropical lagoon. Mar Ecol Prog Ser 358:1-12

Kremer JN, Kemp WM, Giblin AE, Valiela I, Seitzinger SP, Hofmann EE (2000) Linking biogeochemical processes to higher trophic levels. In: Hobbie JE (ed) Estuarine science: a synthetic approach to research and practice. Island Press, Washington, DC, p 299-346

Mackenzie AL, Gillespie PA (1986) Plankton ecology and productivity, nutrient chemistry, and hydrography of Tasman Bay, New Zealand, 1982-84. NZ J Mar Freshw Res 20: 365-395

> Malone TC, Crocker LH, Pike SE, Wendler BW (1988) Influences of river flow on the dynamics of phytoplankton production in a partially stratified estuary. Mar Ecol Prog Ser 48:235-249

Mann KH, Lazier JRN (1991) Dynamics of marine ecosystems. Blackwell Scientific, Boston

McKerchar AI (2001) Streamflow. In: Meyers, RA (ed) Encyclopedia of physical science and technology, 3rd edn, Vol 16. Academic Press, San Diego, CA, p 129-142

$>$ McPhaden MJ, Zebiak SE, Glantz MH (2006) ENSO as an integrating concept in Earth science. Science 314: $1740-1745$

> Monbet Y (1992) Control of phytoplankton biomass in estuaries: a comparative analysis of microtidal and macrotidal estuaries. Estuaries 15:563-571

Mullan AB (1998) Southern hemisphere sea-surface temperatures and their contemporary and lag association with the New Zealand temperature and precipitation. Int J Climatol 18:817-840

New Zealand Marine Farming Association (2007) Fact file: aquaculture industry 2007. www.nzmfa.co.nz/ industryinfo.asp

Peterson DH, Smith RE, Hager SW, Harmon DD, Herndon RE, 
Schemel LE (1985) Interannual variability in dissolved inorganic nutrients in northern San Francisco Bay estuary. Hydrobiologia 129:37-58

Redfield AC, Ketchum BH, Richards FA (1963) The influence of organisms on the composition of seawater. In: Hill MN (ed) The sea, Vol 2. Wiley \& Sons, New York, p 26-77

Ren JS, Ross AH (2005) Environmental influence on mussel growth: a dynamic energy budget model and its application to the greenshell mussel Perna canaliculus. Ecol Modell 189:347-362

Safi KA, Gibbs MM (2003) Importance of different size classes of phytoplankton in Beatrix Bay, Marlborough Sounds, New Zealand, and the potential implications for the aquaculture of the mussel, Perna canaliculus. NZ J Mar Freshw Res 37:267-272

Shearer JJ (1989) Pelorus Sound river water quality during low to medium flows. Marlborough District Council, Blenheim

Smaal AC, van Stralen MR (1990) Average annual growth and condition of mussels as a function of food source. Hydrobiologia 195:179-185

Smith SV, Hollibaugh JT, Dollar SJ, Vink S (1991) Tomales Bay metabolism: C-N-P stoichiometry and ecosystem heterotrophy at the land-sea interface. Estuar Coast Shelf Sci 33:223-257

StatSoft (2005) STATISTICA (data analysis software system), version 7.1. www.statsoft.com

Editorial responsibility: Jana Davis, Annapolis, Maryland, USA
Strohmeier T, Aure J, Duinker A, Castberg T, Svardal A, Strand $\varnothing$ (2005) Flow reduction, seston depletion, meat content and distribution of diarrhetic shellfish toxins in a long-line blue mussel (Mytilus edulis) farm. J Shellfish Res 24:15-23

Uddstrom MJ, Oien NA (1999) On the use of high-resolution satellite data to describe the spatial and temporal variability of sea surface temperatures in the New Zealand region. J Geophys Res 104:20729-20751

Utermöhl H (1958) Zur Vervollkommung der quantitativen Phytoplankton Methodik. Mitt Int Ver Theor Angew Limnol 9:1-38

Verity PG (2002) A decade of change in the Skidaway River estuary. II. Particulate organic carbon, nitrogen and chlorophyll a. Estuaries 25:961-975

Vincent WF, Howard-Williams C, Downes MT, Dryden SJ (1989) Underwater light and photosynthesis at three sites in Pelorus Sound, New Zealand. NZ J Mar Freshw Res 23:79-81

Zeldis JR, Walters RA, Greig MJN, Image K (2004) Circulation over the northeastern New Zealand continental slope, shelf and adjacent Hauraki Gulf, from spring to summer. Cont Shelf Res 24:543-561

Zeldis J, Felsing M, Wilson J (2005) Limits of acceptable change - a stakeholder-collaborative framework for managing environmental performance of New Zealand marine farming. Coastal News 30:1-5. www.coastalsociety.org. nz/back/NZCS30.pdf

Submitted: October 31, 2007; Accepted: July 25, 2008 Proofs received from author(s): October 22, 2008 